\title{
RE-ENVISIONING CONFLICT RESOLUTION
}

VISION, ACTION AND EVALUATION IN CREATIVE CONFLICT ENGAGEMENT 


\section{Re-Envisioning Conflict Resolution}

This book explores the process of assessing success in the field of conflict resolution, with a focus on the Action Evaluation method pioneered by the author.

Since the early days of the field of conflict resolution, researchers and practitioners have been trying to determine how to define and assess success. Are its various approaches to engaging conflict effective? How is effective defined and operationalized and by whom? How might we know? Action Evaluation (AE), a methodology for defining, promoting and assessing success in and of the field, has been developed over the past two decades to answer these questions theoretically and in use. It was designed from its inception to help create sound and contextualized standards around which the field could coalesce. AE is an appropriate methodology for evaluation of conflict engagement, in part because it is grounded in key values of the field, like participation, ownership and the constructive engagement of conflict among stakeholders in project development and implementation. By illustrating how AE is applied through case studies, and providing tools for others to use, this book is intended to make AE a more widely available, user-friendly and rigorous action-research tool for researchers and practitioners in the still-emerging field and beyond.

This book will be of much interest to students of conflict resolution, peace studies, research methods and international relations in general, as well as practitioners in the field.

Jay Rothman is President of the ARIA Group, Inc., a conflict engagement and evaluation consulting firm based in the USA, is Senior Researcher at the Leonard Davis Institute for International Relations at the Hebrew University of Jerusalem and Associate Professor of conflict resolution at Bar-Ilan University, Israel. His latest book is From Identity-Based Conflict to Identity-Based Cooperation: The ARIA Process in Theory and Practice (Springer, 2012). 


\section{Routledge Studies in Peace and Conflict Resolution}

Series Editors: Tom Woodhouse and Oliver Ramsbotham

University of Bradford

Ceasefire Agreements and Peace Processes

A comparative study

Malin Åkebo

Conflict Transformation and the Palestinians

The dynamics of peace and justice under occupation

Edited by Alpaslan Özerdem, Chuck Thiessen and Mufid Qassoum

Peacebuilding and Post-War Transitions

Assessing the impact of external-domestic interactions

Lisa Groß

Resolving Structural Conflicts

How violent systems can be transformed

Richard E. Rubenstein

African Peace Militaries

War, Peace and Democratic Governance

Edited by David J. Francis

Peace Leadership

The Quest for Connectedness

Edited by Stan Amaladas and Sean Byrne

Legitimacy in Peacebuilding

Rethinking Civil Society Involvement in Peace Negotiations

Franzisca Zanker

Re-Envisioning Conflict Resolution

Vision, Action and Evaluation in Creative Conflict Engagement

Jay Rothman

\section{Universities and Conflict}

The role of higher education in peacebuilding and resistance

Edited by Juliet Millican 


\title{
Re-Envisioning Conflict Resolution
}

Vision, Action and Evaluation in

Creative Conflict Engagement

\author{
Jay Rothman
}


First published 2018

by Routledge

2 Park Square, Milton Park, Abingdon, Oxon OX14 4RN

and by Routledge

711 Third Avenue, New York, NY 10017

Routledge is an imprint of the Taylor \& Francis Group, an informa business

(C) 2018 Jay Rothman

The right of Jay Rothman to be identified as author of this work has been asserted by him in accordance with sections 77 and 78 of the Copyright, Designs and Patents Act 1988.

All rights reserved. No part of this book may be reprinted or reproduced or utilised in any form or by any electronic, mechanical, or other means, now known or hereafter invented, including photocopying and recording, or in any information storage or retrieval system, without permission in writing from the publishers.

Trademark notice: Product or corporate names may be trademarks or registered trademarks, and are used only for identification and explanation without intent to infringe.

British Library Cataloguing-in-Publication Data A catalogue record for this book is available from the British Library

Library of Congress Cataloging-in-Publication Data A catalog record for this book has been requested

ISBN: 978-1-138-71744-2 (hbk)

ISBN: 978-1-315-19632-9 (ebk)

Typeset in Times New Roman

by Apex CoVantage, LLC 
This book is dedicated to the memory of my parents - Philip Rothman (1921-2014) and Esther Rothman (1923-2017) - who passed away while I was writing it. They were both master educators. As I describe in the introduction, success and failure ... should be understood most broadly not as judgment but as the basis of learning. I learned this key lesson from them about life in general - and my work in particular - and it has helped me keep perspective about successes and stay resilient about failures. 
$\because$ Taylor \& Francis

Taylor \& Francis Group

http://taylorandfrancis.com 


\section{Contents}

List of Tables

viii

List of figures

ix

Acknowledgments

Introduction

1 What is success in conflict engagement?

2 Epistemologies of peace practice

5 "Just-talk" in action: Cincinnati Police-Community Relations Collaborative

6 New horizons: Systematic collaborative visioning for action and evaluation in creative conflict engagement

7 Appendix

Index 


\section{Tables}

1.1 Conflict Engagement Methodologies 12

1.2 Contingency Approach to Creative Conflict Engagement 14

1.3 What, Why and How Stages at Baseline, Formative and

$\begin{array}{lr}\text { Summative Phases } & 18\end{array}$

$\begin{array}{lll}1.4 & \text { Baseline Stage } & 20\end{array}$

$\begin{array}{lll}1.5 & \text { Formative Stage } & 22\end{array}$

$\begin{array}{lll}1.6 & \text { Summative Stage } & 23\end{array}$

2.1 WHAT Goals: Empiricism 40

2.2 WHY Motivations: Hermeneutics 42

2.3 HOW Practices: Critical Theory 46

3.1 Example of Survey Response 58

$\begin{array}{ll}3.2 & \text { Passion Points and Stories } \\ 3.3 & 59\end{array}$

3.3 Fleeting Visioning Project Shared Vision 63

4.1 Example of What and Why Survey Responses 72

4.2 Example of Why Story 73

$\begin{array}{lll}4.3 & \text { Home } & 74\end{array}$

$\begin{array}{lll}4.4 & \text { Belonging } & 75\end{array}$

$\begin{array}{lll}4.5 & \text { Sharing } & 75\end{array}$

$\begin{array}{lll}4.6 & \text { Dialogue vs. Debate } & 77\end{array}$

5.1 Three Levels of Social Change 90

$\begin{array}{lll}7.1 & \text { Tips to Do } & 122\end{array}$

$\begin{array}{lll}7.2 & \text { Tips to Not Do } & 123\end{array}$

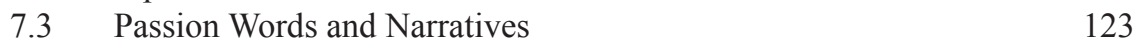

7.4 Can Be Used as a Reference Directions for Facilitator 124

$\begin{array}{lll}7.5 & \text { Straw Poll } & 127\end{array}$

$\begin{array}{ll}7.6 \text { If ... Then } & 128\end{array}$

7.7 Summary of The Consensus-Building Process 131

7.8 Summary of The Action Team Process 134

7.9 Action Strategy Template 1 135

7.10 Action Strategy Template 2 136 


\section{Figures}

$\begin{array}{lll}1.1 & \text { Evaluation Utilization Continuum } & 17\end{array}$

3.1 Why, What and How $\quad 61$

3.2 Vision for Future of Groundfishing Fleet 62

5.1 Six-Stage Cincinnati Collaborative Process 88

7.1 Tree of Goals 118

$\begin{array}{ll}7.2 & \text { Individual Goals } \\ 7.3 & 119\end{array}$

7.3 Shared and Unique Intragroup Goals 119

$\begin{array}{ll}7.4 & \text { Shared and Unique Intergroup Goals } \\ \end{array}$ 


\section{Acknowledgments}

Writing this book has been a 20 -year journey, and in many ways, it is the product of thousands of hands and my very complex and interesting career as a scholarpractitioner moving between the academy and the field. Along the way, I had help and support from many friends, colleagues and family. I will name only a few of them here (with apologies to those I leave out).

Most significantly, I would like to thank my editor, Daniele Natali Goldberg. From outstanding graduate student to trusted colleague, she pushed this book forward with tremendous focus, grace and dedication and ensured its otherwise dubious completion. I also worked previously with additional editors, Israel Sykes and Astrid Reinprecht, who helped me frame this work.

My original partner in this project of developing Action Evaluation, which we conceived together as an appropriate technology for conflict intervention evaluation, was Professor Marc Ross of Bryn Mawr College. Our first funder and ally was Stephen Del Rosso, then of Pew Charitable Trusts. Steve Toben of The Hewlett Foundation joined in funding the next stages of development. Last, Steve Kelban and Sabena Leake of the Andrus Family Foundation partnered with me to move Action Evaluation into the work of social justice (two of the cases in this book - The Cincinnati Police-Community Relations Collaborative and the NAMA Fisheries Project were supported by their partnership). Professor Victor Friedman of Jezreel Valley College in Israel has been my main collaborator in the development of wide dissemination of the Action Evaluation methodology. Another key partner in its early development and application was Bill Withers, originally a student and later a trusted colleague.

My pioneering trainees in the methodology in its early days were Susan Allen, Deborah Bing, Rachael Cobb and Orion Kriegman. Students who have worked with me to test and develop the methodology in their MA or PhD work were Stephanie Stobbe, Ian Johnson, Dale Hotaling and Orit Hammerman-Golan. My outstanding employees and colleagues at my consulting company, the ARIA Group, who helped me further refine and apply the process over the years, included Vaughn Crandall, Rob Mclaughlin, Meghan Clarke and Brandon Sipes. My son, Jesse, has read and commented sagely on various chapters. I am particularly grateful to 
Oliver Ramsbotham, who encouraged and supported me in this project and has helped to marshal it through.

This book has its origins in my own moves between academia and practice where I have tried to link them. I am grateful to the many programs and projects around the world that invited me to work with them and partnered with me to refine this methodology in practice. While there are too many organizations and projects to name (more than 100), I do want to acknowledge those who directly helped with the three cases in this book.

In the first case about the Fisheries project, I am grateful to Craig Pendleton, Mike Crocker and Jen Levin, who were then staff at NAMA, and Niaz Dorry, who is the current director, to Andrew Forsthoefel who researched and wrote a first draft of this chapter, to the aforementioned staff at Andrus Family Fund and to Ken Downing and Jim Tull who, along with my full-time staff (mentioned earlier), consulted with me throughout this complex project. In the second case about intergroup relations at Jezreel Valley College in Israel, I am grateful to my project assistant, Adi Beinart Miller, faculty Victor Friedman and leading staff Nizar Bitar and Javier Simonovich, and to The Abraham Fund staff, Thabet AbuRas and Anwar Elshikha. In the third case about Police-Community relations in Cincinnati, there are literally dozens of staff (paid and volunteer) and thousands of participants I would like to individually thank for their tireless work. Due to space limitations, I will thank only a handful of key colleagues: Steven Kelban, Judge Susan Dlott, Professor John Eck, Attorney Alfonso Gerhardstein, Roger Conner and Amber Thorne-Hamilton.

I am also grateful to the many academic institutions that hosted me over the years as I moved back and forth from field work to theory as I developed Action Evaluation while teaching about it as I researched and developed it in the field (including in the classroom). This began from 1992 to 1998 at Haverford and Bryn Mawr College Peace and Conflict Studies Program (1992-1998). Next from 1998-2001 I moved to the Antioch University Masters Program in Conflict Analysis, Engagement and Management. In 2007 I was a Fulbright Fellow at Jezreel Valley College in Israel. In 2008 until 2011 I was at the University of Cincinnati, I applied Action Evaluation as a consultant to Dean Larry Johnson of the College of Education, Criminal Justice and Human Services using the methodology with his faculty and then stayed on for two more years as a distinguished visiting professor. Most recently, beginning in 2012 I have been an Associate Professor at the Graduate Program on Conflict Resolution, Management and Negotiation at Bar Ilan University. In 2017, I was appointed Senior Researcher at the Leonard Davis Institute for International Relations at Hebrew University. This represents a full circle as I began my Ph.D. field work and later established one of the first conflict resolution programs ("The Jerusalem Peace Initiative") at the Davis Institute from 1986-1992.

Finally, and most of all, I am deeply grateful to my wife, Randi, who has been by my side in developing, refining and helping me write about and live 
xii Acknowledgments

the accomplishments and shortcomings of this process since its inception, on an almost daily basis.

I am grateful to all of these allies, and to the literally thousands of others who have participants who took part in more than 100 Action Evaluation projects across a dozen countries over the last two decades. Of course, all the faults and limitations of this book, and the methodology it describes, are mine alone.

Jay Rothman, Jerusalem and Yellow Springs, Ohio 


\section{Introduction}

What is success in creative conflict engagement? What is failure? Is the first always good and the second always bad? Who says? How do we know, and can we measure it? Should we? What do we gain when we try? What do we lose? Of course, the most common way to evaluate success is by focusing on outcomes. But this may be myopic. Not always is outcome-success a good thing (i.e., if goals are pedestrian or perpetuate a negative status quo), nor is outcome-failure always a bad thing (if success would be unfair or destructive, or if third parties, disputants and other stakeholders gain useful insights from it).

In this book, I suggest that success and failure in creative conflict engagement should be understood most broadly not as judgment but as a process of learning. That is, how much have we (third parties, participants, other stakeholders) learned in the process of engaging conflict and seeking to forge cooperation? What have the various actors learned about themselves, the other side(s) and their shared world? Has this learning pointed to new ways for more constructive conflict engagement in the future? And finally, what are some ways - supportive of the values of the field - we can reliably gather and affirm our answers to this last question? In a recent conversation with a practitioner seeking more effective ways to transfer insights from "track two" encounters among non-official representatives of political leaders (who are attuned to grassroots sentiments and aspirations), we discussed that transfer to "track one" actors need not only be in the form of concrete and specific policy suggestions. Rather, we explored how "success" could be about sharing insights and learning in ways that were accessible and peacepromoting among policymakers and other leaders.

Defining success in conflict resolution is often elusive. Especially when it is only outcome-oriented, as much evaluation often is. This hit home during a recent discussion with a young Palestinian peacemaker, one of the next generation of Israelis and Palestinians that an international group of peace professionals had been training for a few years. This next generation was now taking up leadership. Talking with him reminded me that when we first shared our approaches, he stopped us cold in our tracks with a simple, innocent question: "Your approaches to peace sound interesting, but can you tell me where they have really worked?" I realized then that a key question for and in our field is the meaning of: "does it really work?" We can't answer that until we know, what is our field? And in 
a circular way, in any professional field, knowing how success is defined and by whom is essential to building a community of practice. Conflict itself, in the popular mind, is failure. We in this field know, or should know, better. Conflict is potentially a golden opportunity for learning, development and change. Conflict is the dynamic force within all creativity - in artistic endeavor and human relations. Nothing new is created; no song is sung without friction of one kind or another. Just as we understand that conflict is (or can be) opportunity and indeed forging, fostering, finding and nurturing, that opportunity-from-conflict is really what the field is all about - so we may gain much traction from accepting the outcome that "failure" is a norm in our work and not inherently a negative to avoid, be embarrassed about or deny. Rather, it is or can be an exquisite opportunity for deep learning. In conflict engagement, success and failure are two connected sides of the same coin, and learning how to name, frame, engage and learn from either is necessary for our work and field - and world - to flourish.

Part of the reason we "fail" so much in a way that hurts our field and its image is that we fail "negatively." That is, our aspirations are often unrealistic and set up false expectations that can only be disappointed, and also because our terminology is very ill-defined. One of the pre-founders of our field, Kenneth Boulding (he was more of a leader in peace science that was a precursor to conflict resolution as a field) told me once that he rued the day when he had helped name the first journal in the field, "The Journal of Conflict Resolution." I believe a problem with our field is that we call it Conflict Resolution. I and others advocate that the field be given a new umbrella label of "Conflict Engagement," with Conflict Management, Resolution and Transformation (see bibliographical review in Chapter 1) being three main types rooted in different epistemologies (see chapter 2) by which we creatively engage conflict. Such an emerging superordinate term for our field suggests that each intervention, often including more than one type, would be contingently designed by assessing the form of conflict to be engaged (e.g., resource, goal or identity), and therefore, different outcome goals would be determined. On this basis, it would be possible to systematically define, promote and assess success and failure - both in terms of process and outcomes.

For the field to grow as a discipline, it is essential for us to arrive at a more nuanced and rigorous epistemology of success (which as will be seen in chapter two, I suggest as a kind of conflict and peace epistemology drawn from epistemologies of social science) along with more serious theorizing about the contingent and contextual nature of success in specific conflict cases. Even more important is the as-yet-unrealized theoretical capacity to generalize across such cases, to begin developing islands of theory. In particular, we need a solid contingency approach to be able to generalize from theory and empirical research across cases to better understand which types of interventions are more effective to accomplish which types of goals, in which types and developmental dynamics of conflicts. Surely one of the problems of the field is that it has no unifying theory around which success and failure can be benchmarked. Thus, I searched for and ultimately helped develop a new way - called "Action Evaluation" - described and illustrated in this 
book, to define, promote and assess success that would create adaptable but sound standards around which the field could coalesce.

In the first chapter, I describe the purpose and process of Action Evaluation (AE), developed over the past two decades to systematically inquire into questions of success and failure in Conflict Resolution. It aims at improving and deepening the capacity of the field to take on questions of success in nuanced and contextually appropriate ways. Without this, I claim, the field will remain relatively underdeveloped and unrecognized. In the 1980s as the field began to coalesce into a systematic set of theories and practices ideally to be synthesized and coordinated in to a robust discipline, there was a great sense of an adventurous unfolding in new paths to social, cultural and political peace between individuals, groups, organizations and nations. Today, there is a meandering sense of "where to and how?" The field unfortunately seems to be reflecting a current global malaise about the present and future rather than providing coherence and leadership. Systematically defining, promoting and assessing success in our field, I believe, will help the field to be more grounded, legitimated and effective.

As discussed in Chapter 2, questions of success are essentially applied epistemologies or theories of practice. In shorthand, these are theories of knowledge that guide and condition cognitions and emphases. What knowledge is important to whom, in which setting and why? An AE inquiry begins with the threefold questions asked of individual participants: What are my goals (or definitions of success)? Why do I care about them? How can I best pursue them? It then moves up levels of complexity to ask and answer these same questions at the level of groups and systems. In this chapter, three main theories of knowledge Empiricism, Hermeneutics and Critical Theory - are associated with each of these questions. Empiricism is presented as a way to theoretically ground conceptual questions about what is success. Hermeneutics guides questions of motivations why does one care - in an interpretive framework. Finally, Critical Theory is presented as a way to guide and energize questions of how people achieve goals that are both transformative and lasting.

All practice - including evaluation - is guided by theories of knowledge that are often implicit. In gaining explicit awareness about conceptual frameworks - or epistemologies - beneath different types of practices, actors can become more volitional about their decisions. This is a form of reflexive - or interactive - practice, in which knowledge about one's theories is matched with language and practice to enact them. For example, "I believe in win-win solutions to conflicts (theory); therefore, I seek to foster a cooperative dialogue (language) in which everyone's goals are defined and as much as possible, are met (practice)." In building a systematic approach to conflict engagement evaluation, a self-reflexive awareness in which one is both subject and object of inquiry is the starting point in the search for success in definitions and actions. From there the relational dynamic between self-knowing individuals in some group context having achieved relational reflexivity about success is the next step (i.e., intragroup reflexivity). Finally, at the level of most complexity, the community of groups - wherein individuals constitute 


\section{Introduction}

their groups, which in turn constitute the community of groups - reach deep intersubjective agreement about what constitutes success, in theory and in practice (i.e., intergroup reflexitivity). While seeking to intersect theory and practice through epistemological knowing and reflexive practice can be a rather daunting undertaking, AE as described in this chapter is designed to make this effort practical and doable.

In Chapter 3, the first case study of an application of AE to an environmental dispute is presented. Its focus is on the epistemology of empiricism at the baseline or definitional stage of Action Evaluation. What do the various key stakeholders in an AE - individually, in the context of their identity-groups and across them - define in specific and concrete terms as success? The case presented in this chapter is about the future of New England Fisheries Management. It examines the several-year Action Evaluation project called "The Fleet Visioning Project" (FVP) and describes the process by which individuals and groups arrived at consensus around concrete what-goals, and began gaining a sense of agency and cooperation regarding shared problems and their remedies.

In Chapter 4, the second case study, about intergroup relations, is presented. Its focus is on the epistemology of hermeneutics - or why the goals at stake are particularly meaningful - at the formative phase of AE. Why do the various key stakeholders in an AE - individually, also in terms of their identity groups and across them - view these goals as their individual, group and system-level definitions of success? The AE project described in this chapter was conducted over a two-year period by approximately 100 Arab and Jewish faculty, administrators and students at Jezreel Valley College in Northern Israel. This case study is about the use of AE to help build a "community of practice," in which diverse participants worked together to define and promote success in their relationships on their campus. Through an interpretive, hermeneutic lens, this chapter explores the story of this project, which asked a wide range of stakeholders to reflect together in a sustained way and in a participative and egalitarian manner about their goals and actions for improving their understanding about and relationships with each other.

The fifth chapter is about applying AE to intervene in fraught police-community relations in Cincinnati, Ohio, by helping thousands of stakeholders to define and design success for improving them. In this case study the focus is on the epistemology of critical theory - and how the formulation and practices of AE can be transformative in conceptualizing and sustaining new notions of success. In 2001 a young African American man was shot and killed by the police in Cincinnati, Ohio. Similar to deadly clashes occurring around the U.S. with increasing frequency, a standoff ensued between the African American community and the police. Alternatively called "unrest" (by African American activists suggesting a rebellion to a long-term dynamic), and "riots" (by media, police and city officials suggesting a kind of spontaneous combustion), momentum for change was seized. Cooperative and non-violent action unfolded, as rage and fear were channeled through AE into a massive visioning process for the future. A campaign was launched to "Get Out the Voice" for a new future, and some 3,500 people shared their ideals for what it might look like. What did they want? Community-oriented problem-solving 
policing. Why did they care? They needed to be heard and respected. How did they want to implement their new vision? By fostering joint efforts - by police and with community partnership - to proactively and cooperatively address crime and disorder. Thus, the "Cincinnati Police-Community Relations Collaborative" was unfolded over a 12-month process. Policing was transformed in Cincinnati, and a new model was forged.

In Chapter 6, AE in general and this book in particular are summarized as aiming to "help good people do good work together, better." It begins with a review of innovations and applications of AE. Strengths and weaknesses of AE are then detailed. Finally, the chapter concludes with my own mini-AE about my aspirations for the future of $\mathrm{AE}$ and an invitation to you, my readers, to join me and many other colleagues around the world who have collaborated in building this methodology so far, as we look forward to its further unfolding in the future.

The appendix provides a step-by-step way for readers of this book to apply it in their own settings. I provide a script around which I am hopeful readers will learn how it's been done over the years by others and then will improvise their own ways as they adapt and improve upon it in their own theorizing and practices. Moreover, I hope they (you) will share innovations with what I envision as a growing community of practice among folks using and improving upon the methodology. Internet links for readers to "try it out" and worksheets and how-to guidance are provided as well. Already a product of thousands of hands - hearts and minds - my goal is for a multiplier effect as the field of creative conflict engagement grows to maturity in part with the aid of this book and iteratively assists AE to become even more useful as the field matures

It is my hope that this book and the methodology presented in it, the theories that drive it and some experiences about applying it, will through its readers who may use and adapt it to contribute to growing the field of creative conflict engagement as a more grounded, legitimated and effective one, thereby fostering some more pieces of peace in our broken world. 


\section{What is success in conflict engagement?}

Alberstein, M. (2013). In Search of Identity for the Field of Conflict Resolution. International Journal of Conflict Engagement and Resolution, 1 (2), 135-146.

Alberstein, M. , \& Rothman, J. (2013). Taking Stock of the Field: Past, Present and Future. An Introduction. International Journal of Conflict Engagement and Resolution, 1 (1), 3-9.

Allen-Nan, S. (2003). Formative Evaluation. Available at www.beyondintractabilty.org/essay/formative-evaluation. Last accessed on 6/25/ 16 .

Argyris, C. , Putnam, R. , \& Smith, D. M. (1985). Action Science. San Francisco, CA: JosseyBass.

Avruch, K. (2013). Does Our Field Have a Centre: Thoughts From the Academy. International Journal of Conflict Engagement and Resolution, 1 (1), 10-31.

Avruch, K. , \& Black, P. W. (1991). The Culture Question and Intercultural Conflict Resolution.

Peace and Change, 16, 22.

Azar, E. E. (1990a). The Management of Protracted Social Conflicts: Theory and Cases.

Aldershot, UK: Dartmouth Publishing Company.

Azar, E. E. (1990b). Protracted International Conflicts: Ten Propositions. In Burton, J. \& Dukes, F. (Eds.). Conflict: Readings in Management and Resolution (pp. 145-155). London, UK:

Palgrave Macmillan.

Banks, M. (1990). The International Relations Discipline: Asset or Liability for Conflict Resolution? In Burton, J. \& Dukes, F. (Eds.). Conflict: Readings in Management and Resolution (pp. 51-70). London, UK: Palgrave Macmillan.

Brydon-Miller, M. , Greenwood, D. , \& Maguire, P. (2003). Why Action Research? Action Research, 1 (1), 9-28.

Burton, J. W. (1966). Conflict as a Function of Change. In de Reuck, A. \& Knight, J. Ciba Foundation Symposium-Conflict in Society (pp. 370-401). Hoboken, NJ: John Wiley \& Sons. Burton, J. W. (1987). Resolving Deep-Rooted Conflict: A Handbook. Lanham, MD: University Press of America.

Bush, R. A. B. , \& Folger, J. P. (1997). The Promise of Mediation: The Transformative Approach to Conflict. Hoboken, NJ: John Wiley \& Sons.

Coleman, P. T. (2011). The Five Percent: Finding Solutions to Seemingly Impossible Conflicts. New York, NY: Public Affairs.

Coleman, P. T. (2013). Crisis and Opportunities: Six Contemporary Challenges for Increasing Probabilities for Sustainable Peace . International Journal of Conflict Engagement and Resolution, 1 (96).

Deutsch, M. (1977). The Resolution of Conflict: Constructive and Destructive Processes. New Haven, CT: Yale University Press.

Deutsch, M. (1994). Constructive Conflict Resolution: Principles, Training, and Research. Journal of Social Issues, 50 (1), 13-32.

Elliott, M. , Pearson-d'Estrée, T. , \& Kaufman, S. (2003). Evaluation as a Tool for Reflection. In Burgess, G. , \& Burgess, H. (Eds.). Beyond Intractability. Conflict Information Consortium, University of Colorado, Boulder. Posted: September 2003. Available at www.beyondintractability.org/essay/evaluation-reflection. Last accessed on 6/19/ 16.

Fetterman, D. M. , Kaftarian, S. , and Wandersman, A. (1995). Empowerment evaluation: Knowledge and tools for self-assessment and accountability. Thousand Oaks, CA: Sage.

Fisher, R. , \& Ury, W. (1978). International Mediation, a Working Guide: Ideas for the Practitioner. Washington, DC: International Peace Academy.

Fisher, R. , \& Ury, W. (1987). Getting to Yes. London, UK: Penguin.

Freire, P. (1970). Pedagogy of the Oppressed. New York: Herder and Herder.

Gilligan, C. (1982). In a Different Voice. Cambridge, MA: Harvard University Press.

Habermas, J. (1984). The Theory of Communicative Action, Vol. 1: Reason and the Rationalization of Society ( T. McCarthy, Trans.). Boston, MA: Beacon Press.

Hocker, J. L. , \& Wilmot, W. W. (1985). Interpersonal Conflict. New York, NY: WCB/McGrawHill.

Kelman, H. C. (1972). The Problem-Solving Workshop in Conflict Resolution. In Merritt, R. L. (Ed.). Communication in International Politics (pp. 168-204). Champaign, IL: University of Illinois Press. 
Kelman, H. C. (1990). Interactive Problem-Solving: A Social-Psychological Approach to Conflict Resolution. In Burton, J. \& Dukes , F. (Eds.). Conflict: Readings in Management and Resolution (pp. 199-215). London, UK: Palgrave Macmillan.

Kissinger, H. A. (1962). The Necessity for Choice: Prospects of American Foreign Policy. New York, NY: Doubleday.

Lederach, J. P. (1995). Preparing for Peace: Conflict Transformation Across Cultures. Syracuse, NY: Syracuse University Press.

Lederach, J. P. (1997). Building Peace: Sustainable Reconciliation in Divided Societies.

Washington, DC: United States Institute of Peace.

Lewin, K. (1951). Field Theory in Social Science. New York, NY: Harper.

Mayer, B. (2009). Staying With Conflict: A Strategic Approach to Ongoing Disputes. Hoboken, $\mathrm{NJ}$ : John Wiley \& Sons.

McGuigan, R. J. , \& Popp, N. (2016). Integral Conflict: The New Science of Conflict. Albany, NY: State University of New York Press.

Mitchell, C. R. (1988). New Approaches to International Mediation (No. 223). Westport, CT: Praeger Publishers.

Morgenthau, H. , \& Nations, P. A. (1948). The Struggle for Power and Peace. New York, NY: Alfred A. Knopf.

Nan, S. , \& Strimling, A. (2006). Coordination in Conflict Prevention, Conflict Resolution and Peacebuilding. International Negotiation, 11 (1), 1-6.

Patton, M. Q. (1990). Qualitative Evaluation and Research Methods. Thousand Oaks, CA: Sage

Publications.

Patton, M. Q. (1997). Utilization-Focused Evaluation: The New Century Text. Edition 3.

Thousand Oaks, CA: Sage Publications.

Ramsbotham, O. (2013). Radical Disagreement and Systemic Conflict Transformation. In Körppen, D. , Ropers, N. , \& Giessmann, H. J. (Eds.). The Non-Linearity of Peace Processes Theory and Practice of Systemic Conflict Transformation (pp. 57-76). Opladen and Farmington Hill: Barbara Budrich Publishers.

Ramsbotham, O. (2017). When Conflict Resolution Fails. Malden, MA: Polity Press.

Ross, M. (2001). Action Evaluation in the Theory and Practice of Conflict Resolution. Peace and Conflict Studies, 8 (1), Article 1. Available at http://nsuworks.nova.edu/pcs/vol8/iss1/1

Ross, M. , \& Rothman, J. (eds.) (1999). Theory and Practice in Ethnic Conflict Management: Conceptualizing Success and Failure. London: Macmillan Press.

Rothman, J. (1989). Thinking and Acting for Peace: Applying the Problem Solving Workshop Approach to Improving Intergroup Relations between Jews and Arabs in Israel. Ph.D.

Dissertation, University of Maryland.

Rothman, J. (1992/2012). From Confrontation to Cooperation: Resolving Ethnic and Regional Conflict. Thousand Oaks, CA: Sage Publications (republished as an eBook in 2012).

Rothman, J. (1996). Reflexive Dialogue as Transformation. Mediation Quarterly, 13 (4), 345-352.

Rothman, J. (1997). Resolving Identity-Based Conflicts in Nations, Organizations and Communities. San Francisco: Jossey-Bass.

Rothman, J. (1999). Articulating Goals and Monitoring Progress in a Cyprus Conflict Resolution Training Workshop. In Ross, M. , \& Rothman, J. (Eds.) Theory and Practice in Ethnic Conflict Management: Conceptualizing Success and Failure (pp. 176-194). London: Macmillan Press. Rothman, J. (2014). Conflict Engagement: A Contingency Model in Theory and Practice. Peace and Conflict Studies, 21 (2), 104-116.

Rothman, J. , \& Alberstein, M. (2013). Individuals, Groups and Intergroups: Understanding The Role of Identity in Conflict and its Creative Engagement. The Ohio State Journal on Dispute Resolution, 28 (3).

Rothman, J. , \& Friedman, V. J. (2001). Action Evaluation for Knowledge Creation in SocialEducation Programs. In Sankaran, S. (Ed.). Effective Change Management Using Action Learning and Action Research. Australia: Southern Cross University Press.

Rubin, J. Z. (1989). Some Wise and Mistaken Assumptions About Conflict and Negotiation. Journal of Social Issues, 45 (2), 195-209.

Scimecca, J. A. (1991). Conflict Resolution and a Critique of Alternative Dispute Resolution. In Pepinsky, H. E. , \& Quinney, R. (Eds.). From Criminology as Peacemaking (pp. 263-279).

Bloomington, IN: Indiana University Press. 
Scriven, M. (1991). Beyond Formative and Summative Evaluation. In McLaughlin, M. W. , \& Phillips, E. D. C. (Eds.). Evaluation and Education: A Quarter Century. Chicago, IL: University of Chicago Press.

Senge, P. (1994). Building Learning Organizations. In Schneier, C. E. , Russell, C. J. , Beatty, R. W. , \& Baird, L. S. (Eds.). The Training and Development Sourcebook. Amherst, MA: Human Resource Development Press.

Shapiro, D. L. (2002). Negotiating Emotions. Conflict Resolution Quarterly, 20 (1), 67-82.

Snyder, J. L. (2000). A Critical Theory of Peace Practice: Discourse Ethics and Facilitated Conflict Resolution. Ph.D. Dissertation, The London School of Economics and Political Science. Stobbe, S. P. (2015). Conflict Resolution and Peacebuilding in Laos: Perspective for Today's World (Vol. 73). Abingdon, UK: Routledge.

Stone, D. , Heen, S. , \& Patton, B. (1999). Difficult Conversations: How to Discuss What Matters Most. London, UK: Penguin.

Susskind, L. , \& Field, P. (1996). Dealing With an Angry Public: The Mutual Gains Approach to Resolving Disputes. New York, NY: Simon \& Schuster.

Volkan, V. D. (1988). The Need to Have Enemies and Allies: From Clinical Practice to International Relationships. New York: Roman and Littlefield.

\section{Epistemologies of peace practice}

Allen-Nan, S. (2011). Consciousness in Culture-Based Conflict and Conflict Resolution. Conflict Resolution Quarterly, 28 (3), 239-262.

Argyris, C. , Putnam, R. , \& Smith, D. M. (1985). Action Science. San Francisco, CA: JosseyBass.

Argyris, C. , \& Schon, D. A. (1974). Theory in Practice: Increasing Professional Effectiveness. San Francisco, CA: Jossey-Bass.

Bernstein, R. J. (1978). The Restructuring of Social and Political Theory. Philadelphia, PA: University of Pennsylvania Press.

Bourdieu, P. , \& Wacquant, L. J. (1992). An Invitation to Reflexive Sociology. Chicago, IL: University of Chicago Press.

Buber, M. (1966). The Way of Man: According to the Teaching of Hasidism (Vol. 50024). New York, NY: Citadel Press.

Buber, M. (1970). I and Thou ( W. Kaufmann , Trans.). Edinburgh, Scotland: T\&T Clark. Cooperrider, D. L. , \& Whitney, D. K. (2005). Appreciative Inquiry: A Positive Revolution in Change. San Francisco, CA: Berrett-Koehler.

Cunliffe, A. L. (2009). The Philosopher Leader: On Relationalism, Ethics and Reflexivity - A Critical Perspective to Teaching Leadership. Management Learning, 40 (1), 87-101.

Doucet, A. , \& Mauthner, N. (1998). Voice, Reflexivity, and Relationships in Qualitative Data Analysis. Background paper for workshop on Voice in Qualitative Data Analysis.

Fetterman, D. M. (2001). Foundations of Empowerment Evaluation. Thousand Oaks, CA: Sage Publications.

Freire, P. (2000). Pedagogy of the Oppressed. London, UK: Bloomsbury Publishing.

Friedman, V. J. , Rothman, J. , \& Withers, B. (2006). The Power of Why: Engaging the Goal

Paradox in Program Evaluation. American Journal of Evaluation, 27 (2), 201-218.

Friedman, V. J. , Rothman, J. , \& Withers, B. (2012). The Power of Why. In Rothman, J. (Ed.).

From Identity-Based Conflict to Identity-Based Cooperation (pp. 21-33). New York, NY:

Springer.

Habermas, J. (1970). Towards a Theory of Communicative Competence. Inquiry, 13 (1-4), 360-375.

Habermas, J. (1984). Theory of Communicative Action, Volume One: Reason and the Rationalization of Society. Boston, MA: Beacon Press.

Habermas, J. (1987). Theory of Communicative Action. Volume Two: Lifeworld and System: A Critique of Functionalist Reason. Boston, MA: Beacon Press.

Habermas, J. (1995). Justification and Application: Remarks on Discourse Ethics. Cambridge, MA: MIT Press. 
Habermas, J. (2014). The Lure of Technocracy. Malden, MA: Polity Press.

Hirschman, A. O. (1970). Exit, Voice, and Loyalty: Responses to Decline in Firms,

Organizations, and States (Vol. 25). Cambridge, MA: Harvard University Press.

Horkheimer, M. (1972). Critical Theory. New York, NY: Seabury Press.

Pillow, W. (2003). Confession, Catharsis, or Cure? Rethinking the Uses of Reflexivity as

Methodological Power in Qualitative Research. International Journal of Qualitative Studies in

Education, 16 (2), 175-196.

Polanyi, M. (1966). The Logic of Tacit Inference. Philosophy, 41 (155), 1-18.

Polanyi, M. , \& Sen, A. (2009). The Tacit Dimension. Chicago, IL: University of Chicago Press.

Popper, K. R. (2002). The Poverty of Historicism. Hove, UK: Psychology Press.

Preskill, H. , \& Torres, R. (1998). Evaluative Inquiry for Learning in Organizations. Newburry

Park, CA: Sage Publications.

Ross, M. H. (2001). Action Evaluation in the Theory and Practice of Conflict Resolution. Peace and Conflict Studies, 8 (1), 1-15.

Rothman, J. (1989). Supplementing Tradition: A Theoretical and Practical Typology for International Conflict Management. Negotiation Journal, 5 (3), 265-277.

Rothman, J. (1992). From Confrontation to Cooperation: Resolving Ethnic and Regional Conflict (Vol. 6). Thousand Oaks, CA: Sage Publications.

Rothman, J. (1997). Action Evaluation and Conflict Resolution Training: Theory, Method and Case Study. International Negotiation, 2 (3), 451-470.

Rothman, J. (2012). Action Evaluation in Theory and Practice. In Rothman, J. (Ed.). From Identity-Based Conflict to Identity-Based Cooperation (pp. 125-133). New York, NY: Springer. Rothman, J. (2014). Action Evaluation. In Coghlan, D. , \& Brydon-Miller, M. (Eds.).

Encyclopedia of Action Research. Thousand Oaks, CA: Sage Publications.

Wenger, E. (2008). Communities of Practice: Learning, Meaning, and Identity. Cambridge, UK: Cambridge University Press.

\section{Gone fishing}

Crocker, M. (2008). Sharing the Ocean: Stories of Science, Politics, and Ownership in America's Oldest Industry. Gardiner, ME: Tilbury House Publishers.

Curtin, C. (2011). Integrating and Applying Knowledge From Community-Based Collaboratives: Implications for Natural Resource Management. In Dukes, E. F. , Firehock, K. , \& Birkhoff, J. (Eds.). Community-Based Collaboration: Bridging Socio-Ecological Research and Practice (pp. 19-44). Charlottesville, VA: University of Virginia Press.

Rothman, J. (1989). Thinking and Acting for Peace: Applying the Problem Solving Workshop Approach to Improving Intergroup Relations Between Jews and Arabs in Israel. Ph.D.

Dissertation, University of Maryland.

van Fraassen, B. (1980). The Scientific Image. Oxford, UK: Oxford University Press.

\section{The Power of Why: Reflection as Practice}

Argyris, C. , \& Schön, D. A. (1985). Action Science: Concepts, Methods, and Skills for Research and Intervention. San Francisco, CA: Jossey-Bass.

Argyris, C. , \& Schön, D. A. (1996). Organizational Learning II: Theory, Method and Practice.

San Francisco, CA: Jossey-Bass.

Arieli, D. , \& Friedman, V. J. (2013). Negotiating Reality: Conflict Transformation in Natural

Spaces of Encounter. The Journal of Applied Behavioral Science, 49 (3), 308-332.

Boulding, K. (1989). Three Faces of Power. Newbury Park, CA: Sage Publications.

Bruner, J. (1987). Life as Narrative. Social Research, 54 (1), 11-32.

Ernst, C. , \& Chrobot-Mason, D. (2011). Boundary Spanning Leadership. New York, NY:

McGraw-Hill. 
Friedman, V. J. , Razer, M. , \& Sykes, I. (2004). Towards a Theory of Inclusive Practice: An Action Science Approach. Action Research, 2 (2), 167-189.

Friedman, V. J. , Rothman, J. , \& Withers, B. (2006). The Power of Why: Engaging the Goal

Paradox in Program Evaluation. American Journal of Evaluation, 27 (2), 201-218.

Friedman, V. J. , Rothman, J. , \& Withers, B. (2012). The Power of Why. In Rothman, J. (Ed.).

From Identity-Based Conflict to Identity-Based Cooperation (pp. 21-33). New York, NY:

Springer.

Hertz, R. (1997). Reflexivity \& Voice. Thousand Oaks, CA: Sage Publications.

Lederach, J. P. (1995). Preparing for Peace: Conflict Transformation Across Cultures.

Syracuse, NY: Syracuse University Press.

Pillow, W. (2003). Confession, Catharsis, or Cure? Rethinking the Uses of Reflexivity as

Methodological Power in Qualitative Research. International Journal of Qualitative Studies in

Education, 16 (2), 175-196.

Raelin, J. A. (2001). Public Reflection as the Basis of Learning. Management Learning, 32 (1), 11-30.

Rothman, J. (1992). From Confrontation to Cooperation: Resolving Ethnic and Regional Conflict. Newbury Park, CA: Sage Publications.

Rothman, J. (1996). Reflexive Dialogue as Transformation. Mediation Quarterly, 13, 345-352.

Rothman, J. (1997). Resolving Identity-Based Conflicts in Nations, Organizations and

Communities. San Francisco, CA: Jossey-Bass.

Rothman, J. (2012). From Identity-Based Conflict to Identity-Based Cooperation. New York, NY: Springer Publications.

Rothman, J. (2014). From Intragroup Conflict to Intergroup Cooperation. In Woehrle, L. M. Intersectionality and Social Change (pp. 107-123). Bingley, UK: Emerald Group Publishing Limited.

\section{"Just-talk" in action}

Aragon, R. A. , \& Burgess, J. (April 15, 2016). Is Collaborative Agreement Working? Conference Examines How Police, Community are Getting Along. WCPO-9 Cincinnati. Available at www.wcpo.com/news/local-news/hamilton-county/cincinnati/is-collaborative-agreementworking-conference-examines-how-police-community-are-getting-along Argyris, C. , Putnam, R. , \& Smith, D. M. (1985). Action Science. San Francisco, CA: JosseyBass.

Bernstein, R. J. (1978). The Restructuring of Social and Political Theory. Philadelphia, PA: University of Pennsylvania Press.

Bidwell, A. Black and Blue: The Cincinnati Collaborative Agreement. Available at https://soundcloud.com/user-649372779/black-and-blue-the-cincinnati-collaborative-agreement1. Last accessed 6/4/17.

Bidwell, A. (2017). Black and Blue: How the Cincinnati Collaborative Agreement Addressed Police Community Relations and Social Trust With the African American Community. Presented to the Conflict and Dispute Resolution Master's Program, School of Law, of the University of Oregon in Fulfillment of the requirements for the Degree of Master of Science June 2017. Burton, J. W. (1979). Deviance, Terrorism \& War: The Process of Solving Unsolved Social and Political Problems. Basingstoke, UK: Palgrave Macmillan.

Eck, J. E. , \& Rothman, J. (2006). Police-Community Conflict and Crime Prevention in Cincinnati, Ohio. In Bailey, J. (Ed.). Public Security and Police Reform in the Americas (pp. 225-244). Pittsburgh, PA: University of Pittsburgh Press.

Gerhardstein, A. (2009). Can Effective Apology Emerge Through Litigation. Law \& Contemporary Problems, 72, 271.

Habermas, J. (1985). Theory of Communicative Action: Vol. II: Lifeworld and System: A Critique of Functionalist Reason. Boston, MA: Beacon Press.

Heifetz, R. A. (1994). Leadership Without Easy Answers. Cambridge, MA: Belknap Press.

Horkheimer, M. (1972). Critical Theory. New York: The Seabury Press. 
Lederach, J. P. (2001). Civil Society and Reconciliation. In Crocker, C. A. , Hampson, F. O. , \& Aall, P. (Eds.). Turbulent Peace: The Challenges of Managing International Conflict (pp. 841-854). Washington, DC: U.S. Institute of Peace Press.

Moynihan, D. P. (1997). The Negro Family: The Case for National Action (1965). Washington, DC: United States Department of Labor.

Rothman, J. (2003). Improving Police-Community Relations in Cincinnati: A Collaborative Approach. ACResolution, 3 (1), 25-27.

Rothman, J. (2006). Identity and Conflict: Collaboratively Addressing Policy-Community Conflict in Cincinnati, Ohio. Ohio State Journal on Dispute Resolution, 22, 105.

Rothman, J. (2012). Applying Action Evaluation on a Large Scale: Cincinnati Police-Community Relations Collaborative - Successes, Failures and Lessons Learned. In Roth-man, J. (Ed.). From Identity-Based Conflict to Identity-Based Cooperation (pp. 191-205). New York, NY: Springer.

Rothman, J. (2015). The Cincinnati Police-Community Relations Collaborative as a National Model of Police-Community Relations Today. In Mediation.com. Available at www.mediate.com//articles/RothmanJ1.cfm

Rothman, J. , \& Soderquist, C. (2002). From Riots to Resolution: Engaging Conflict for Reconciliation. The Systems Thinker, 13 (8), 2-6.

Thorne-Hamilton, A. (2017). Cincinnati Collaborative Agreement Process: Deliberative Democracy as a Method of Improving Police-Community Relations. Ph.D. Dissertation, Kent State University.

\section{New horizons}

Allen-Nan, S. A. (2003). Formative Evaluation. In Burgess, G. , \& Burgess, H. (Eds.). Beyond Intractability. Conflict Information Consortium, University of Colorado, Boulder. Available at www.beyondintractability.org/essay/formative-evaluation

Dewey, J. (1933). How We Think: A Restatement of the Relation of Reflective Thinking to the Educative Process. Lexington, MA: Heath \& Company.

Kelman, H. C. (1990). Interactive Problem-Solving: A Social-Psychological Approach to Conflict Resolution. In Burton, J. \& Dukes, F. (Eds.). Conflict: Readings in Management and Resolution (pp. 199-215). London, UK: Palgrave Macmillan.

Patton, M. Q. (1990). Qualitative Evaluation and Research Methods. Thousand Oaks, CA: Sage Publications.

Ramsbotham, O. (2017). When Conflict Resolution Fails. Malden, MA: Polity Press.

Ross, M. , \& Rothman, J. (eds.) (1999). Theory and Practice in Ethnic Conflict Management:

Conceptualizing Success and Failure. London: Macmillan Press.

Rothman, J. (1997). Resolving Identity-Based Conflicts in Nations, Organizations and Communities. San Francisco, CA: Jossey-Bass.

Rothman, J. (2012). From Identity-Based Conflict to Identity-Based Cooperation. New York, NY: Springer Publications.

Rothman, J. , \& Alberstein, M. (Eds.). (2013). Taking Stock of the Field of Conflict Engagement. International Journal of Conflict Engagement and Resolution, 1 (1), (2).

Schecter, C. , Sykes, I. , \& Rosenfeld, J. (2004). Learning From Success: A Leverage for

Transforming Schools Into Learning Communities. Planning and Changing, 35 (1), (2), 154-168.

Zelka, E. The Art of Failure. Available at www.artoffailure.com. Last accessed 6/15/17. 


\section{Appendix}

Eck, J. E. , \& Rothman, J. (2006). Police-Community Conflict and Crime Prevention in Cincinnati, Ohio: The Collaborative Agreement. In Bailey, J. (Ed.). Public Security and Police Reform in the Americas (pp. 225-244). Pittsburgh, PA: University of Pittsburgh Press.

Friedman, V. J. , Rothman, J. , \& Withers, B. (2012). The Power of Why. In Rothman, J. (Ed.). From Identity-Based Conflict to Identity-Based Cooperation (pp. 21-33). New York, NY: Springer.

Miller, S. , Rothman, J. , Ciaravolo, B. , \& Haney, S. (2012). Embedding Action Evaluation in an Interfaith Program for Youth. In Rothman, J. (Ed.). From Identity-Based Conflict to IdentityBased Cooperation (pp. 175-189). New York, NY: Springer.

Rothman, J. (1997). Action: Setting Joint Agendas. In Resolving Identity-Based Conflict in Nations, Organizations and Communities (pp. 71-84). San Fransisco, CA: Jossey-Bass.

Rothman, J. (1999). Articulating Goals and Monitoring Progress in a Cyprus Conflict Resolution Training Workshop. In Ross, M. , \& Rothman, J. (Eds.). Theory and Practice in Ethnic Conflict Management: Theorizing Success and Failure (pp. 176-194). London, UK: Macmillan Press.

Rothman, J. (2012). Action Evaluation in Theory and Practice. In Rothman, J. (Ed.). From Identity-Based Conflict to Identity-Based Cooperation (pp. 125-133). New York, NY: Springer. Rothman, J. (2014). Action Evaluation. In Coghlan, D. , \& Brydon-Miller, M. (Eds.).

Encyclopedia of Action Research. London, UK: Sage.

Rothman, J. , \& Friedman, V. J. (2001). Action Evaluation for Knowledge Creation in Social-

Education Programs. In Sankaran, S. (Ed.). Effective Change Management Using Action

Learning and Action Research. Australia: Southern Cross University Press.

Rothman, J. , \& Friedman, V. J. (2002). Action Evaluation for Conflict Management

Organization and Project. In Davies, J. , \& Kaufman, E. (Eds.). Second Track/Citizen's

Diplomacy (pp. 57-66). London, UK: Rowman \& Littlefield Publishers, Inc.

Rothman, J. , \& Friedman, V. J. (2014). Action Evaluation: A Method for the Participative Definition, Monitoring, and Assessment of Success in Social Innovation and Conflict Engagement. In Bradbury, H. (Ed.). The SAGE Handbook on Action Research. London, UK: Sage.

Friedman, V. J. , Rothman, J. , \& Withers, B. (2006). The Power of Why: Engaging the Goal Paradox in Program Evaluation. American Journal of Evaluation, 27 (2), 201-218.

Rothman, J. (1997). Action Evaluation and Conflict Resolution: In Theory and Practice. Conflict Resolution Quarterly, 15 (2), 119-131.

Rothman, J. (1997). Action Evaluation and Conflict Resolution Training: Theory, Method and Case Study. International Negotiation, 2 (3), 451-470.

Rothman, J. (2003). Improving Police-Community Relations in Cincinnati: A Collaborative Approach. ACResolution, 3 (1), 25-27.

Rothman, J. (2006). Identity and Conflict: Collaboratively Addressing Policy-Community Conflict in Cincinnati, Ohio. Ohio State Journal on Dispute Resolution, 22, 105.

Rothman, J. , \& Land, R. (2004). The Cincinnati Police-Community Relations Collaborative. Criminal Justice, 18 (4), 34-42.

Rothman, J. , \& Soderquist, C. (2002). From Riots to Resolution: Engaging Conflict for Reconciliation. The Systems Thinker, 13 (8), 2-6.

Darling, I. (1998). Action Evaluation and Action Theory: An Assessment of the Process and Its Connection to Conflict Resolution. Thesis for MA. In Conflict Resolution, Antioch University McGregor Program on Conflict Resolution.

Hotaling, D. (2000). Action Evaluation of Staff Well-Being Issues at Green County Children Services Board. Thesis for MA. In Conflict Resolution, Antioch University McGregor Program on Conflict Resolution.

Johnson, I. (2001). Helping People to Help Themselves: Process Facilitations, Evaluation and Empowerment in an Indigenous Context. Thesis for MA. In Conflict Resolution, Antioch University McGregor program on Conflict Resolution.

Stobbe, S. (1999). Action Evaluation Research: A Tool for the Development and Assessment of Conflict Resolution Curricula. Thesis for MA. In Conflict Resolution, Antioch University McGregor program on Conflict Resolution.

For an overview of $A E$ theory and practice see www.ariagroup.com/?page_id=5

Hoffman, M. (2001). Peace and Conflict Impact Assessment Methodology: Evolving Art Form or Practical Dead End? Berghof Research Center for Constructive Conflict Management. Available 
at www.berghof-center.org/handbook/hoffman/final.pdf

Ross, M. H. (2001). Action Evaluation in the Theory and Practice of Conflict Resolution. George Mason University: Network of Peace and Conflict Studies. Available at www.gmu.edu/academic/pcs/Ross81PCS.html

Rothman, J. Action Evaluation: A Response to Mark Hoffman's Comments. Berghof Research Center for Constructive Conflict Management. Available at www.berghofhandbook.net/rothman/final.pdf

Rothman, J. (2003). Action Evaluation in Theory and Practice. Available at www.beyondintractability.org/m/action_evaluation.jsp 